\title{
Lateritic cement- and lime-stabilised bricks and blocks for affordable housing
}

Festus A. Olutoge BEng, MSc, PhD, COREN Regd, MNSE, MICI Reader, Department of Civil Engineering, University of Ibadan, Ibadan, Nigeria (corresponding author: folutoge2002@yahoo.com)

Colin A. Booth BSC, MSC, PhD, PGCert HE, FRGS, ICIOB

Associate Head for Research and Scholarship, Faculty of Engineering and Technology, University of the West of England, Bristol, UK

\begin{abstract}
Simon Olayiwola A. Olawale BSc, PhD, MNSE, COREN Regd Senior Lecturer, Department of Civil Engineering, Osun State University, Osogbo, Nigeria
\end{abstract}

Olaolu A. Alebiosu BSC

Research Student, Department of Civil Engineering, University of Ibadan, Ibadan, Nigeria

The compressive strengths of cement- and lime-stabilised lateritic bricks and blocks were investigated for economical construction in developing countries. Cement-stabilised lateritic blocks and bricks were found to have the best performance and are thus recommended for use.

\section{Introduction}

Blocks and bricks are important elements of building structures and have a great influence on the cost of construction of a building project. These elements, generally made from cement and sand, have monopoly in the building industry. Overdependence on the utilisation of sandcrete blocks for buildings has kept the financial cost of these blocks as walling units in buildings high. This has deterred underdeveloped and poor nations of the world from providing houses for rural dwellers who constitute the higher percentage of population and who are mostly agriculturally dependent and characterised by a low standard of living. It is therefore important to intensify efforts towards the provision of alternative low-cost walling materials in order to offset the high cost of sandcrete blocks coupled with the low-strength properties of other commercially available materials.

Sandcrete blocks consist of ordinary Portland cement and natural clean sand mixed with water in selected proportions. Sandcrete blocks are produced in two major forms: lightweight and dense blocks. Light weight blocks are made using either lightweight aggregates or aerated concrete. Dense blocks are made with dense aggregates (Raheem et al., 2010), which include natural sand and crushed rock. Blocks made with such aggregates have densities of $1920-2080 \mathrm{~kg} / \mathrm{m}^{3}$ and may be formed solid or hollow.

The current predicament of the building industry in sub-Saharan Africa and Nigeria in particular Nigeria can be linked to a shortage of building materials and escalating prices of those that are available. Motivated by shortages and high prices, investigations are now being made to determine if, and how, locally available materials such as lateritic soils could be used in the building industry (Agbede and Manasseh, 2008). The availability of laterite in most parts of Nigeria and the low cost of accessing it for use in the construction industry are indications that its use will reduce the cost of production of building materials such as blocks, bricks and concrete (Adam and Agib, 2001).

Laterite is a soil layer that is rich in iron oxide and is derived from a wide variety of rock weathering under strongly oxidising and leading conditions. It forms in tropical and subtropical regions where the climate is humid (Encyclopaedia Britannica, 2016).

The characteristics of a soil can be improved through different methods, including stabilisation. It has been established that the properties of some laterite building bricks abundant in the tropical areas of sub-Saharan Africa can be improved by various methods of stabilisation.

Since the inception of the process of stabilisation, most soil materials that have been considered not useful have found application in many areas of engineering. McNally (1998) reported that improvements in engineering properties as a result of stabilisation can include increases in soil strength (shearing resistance), stiffness (resistance to deformation) and durability (wear resistance), reductions in swelling potential or the dispersity (tendency to deflocculate) of wet clay soils, and other desirable characteristics such as dust proofing when used on and water proofing unsealed roads.

Cement and lime stabilisations are traditional means of improving the engineering properties of soils and can be used for stabilising both base and sub-base materials (Amu et al., 2011; Garber and Hoel, 2000). The addition of lime to reactive finegrained soils has beneficial effects on their engineering properties, including a reduction in plasticity and swelling potential, improved workability, increased strength and stiffness, and enhanced durability. In addition, lime has been used to improve the strength and stiffness properties of unbound base and subbase materials. Lime can be used to treat soils to varying 
degrees, depending on the objective. The least amount of treatment is simply used to dry and temporarily modify soils. Such treatment produces a working platform for the construction of temporary roads. A greater degree of treatment - supported by testing, design and proper construction techniques - produces permanent structural stabilisation of soils.

Ogunbiyi et al. (2014) analysed the engineering properties and cost of production of cement-stabilised clay bricks and sandcrete blocks. Their results indicated that the unit cost of cement stabilised bricks was lower than that of hollow sandcrete blocks, the compressive strength of cement-stabilised bricks was slightly higher than that of hollow sandcrete blocks, all the blocks produced and tested met the minimum required compressive strength for use as wall components in buildings, the square metre cost of cement-stabilised bricks was slightly higher than that of hollow sandcrete blocks, and the cementstabilised bricks compared favourably with hollow sandcrete blocks in terms of engineering properties.

Nagaraj et al. (2014) carried out an experimental study on compressed stabilised earth blocks. The blocks were prepared using lime as a partial replacement for cement. Their results indicated that the replacement of cement with lime improved the long-term build-up of strength as compared with the use of cement alone. The study also revealed that the replacement of cement with lime led to considerable energy savings, resulting in cost reductions in the manufacture of blocks.

The study reported in this paper employed the use of lime and cement in the stabilisation of laterite used in the manufacture of bricks and blocks with the aim of obtaining bricks/blocks with compressive strength able to favourably compete with cement-sand bricks or blocks.

\section{Experimental details}

\subsection{Materials and methods}

The materials used for the production of blocks and bricks in this research were cement, laterite, lime and water.

\subsubsection{Cement}

Locally available Portland limestone cement, CEM II/B-L (purchased in Ibadan, Nigeria), manufactured in conformity with NIS 444-1 (SON, 2003), which is equivalent to BS EN 197-1 (BSI, 2000), was used in this study as a stabilising material. The physical properties and chemical composition of the cement are presented in Tables 1 and 2, respectively. The purpose of using cement was to increase the strength of the lateritic soil before using it for moulding block and bricks. The cement in the lateritic soil was varied in proportions of 0,2 , $4,6,8$ and $10 \%$.
Table 1. Physical properties of cement

$\begin{array}{lc}\text { Property } & \text { Test value } \\ \text { Fineness: } \mathrm{m}^{2} / \mathrm{kg} & 269 \cdot 50 \\ \text { Initial setting time: min } & 207 \\ \text { Final setting time: min } & 345 \\ \text { Consistency: \% } & 37 \cdot 40 \\ \text { Soundness: } \mathrm{mm} & 0.31 \\ \text { 3-d compressive strength: } \mathrm{N} / \mathrm{mm}^{2} & 19 \cdot 35 \\ \text { 7-d compressive strength: } \mathrm{N} / \mathrm{mm}^{2} & 27 \cdot 13 \\ \text { 28-d compressive strength: } \mathrm{N} / \mathrm{mm}^{2} & 50 \cdot 60\end{array}$

Table 2. Chemical composition of cement

\begin{tabular}{lc} 
Compounds & \% (by weight) \\
\hline Calcium oxide $(\mathrm{CaO})$ & 64.00 \\
Silicon dioxide $\left(\mathrm{SiO}_{2}\right)$ & 22.00 \\
Aluminium oxide $\left(\mathrm{Al}_{2} \mathrm{O}_{3}\right)$ & 5.60 \\
Iron oxide $\left(\mathrm{Fe}_{2} \mathrm{O}_{3}\right)$ & 5.20 \\
Sulfur trioxide $\left(\mathrm{SO}_{3}\right)$ & 1.59 \\
Magnesium oxide $(\mathrm{MgO})$ & 0.58 \\
Loss of ignition & 2.49 \\
Lime saturation factor & 0.92 \\
Insoluble residue & 2.5 \\
Tricalcium silicate $\left(\mathrm{C}_{3} \mathrm{~S}\right)$ & 50.83 \\
Dicalcium silicate $\left(\mathrm{C}_{2} \mathrm{~S}\right)$ & 22.30 \\
Tricalcium aluminate $\left(\mathrm{C}_{3} \mathrm{~A}\right)$ & 9.25 \\
Tetracalcium aluminoferrite $\left(\mathrm{C}_{4} \mathrm{AF}\right)$ & 10.90 \\
\end{tabular}

\subsubsection{Lime}

Natural hydraulic lime was also used in this study as a stabilising material for the purpose of increasing the strength of the lateritic soil. The chemical composition of the lime is presented in Table 3. Lime in the lateritic soil was also varied in proportions of $0,2,4,6,8$ and $10 \%$.

\subsubsection{Laterite}

The reddish-brown lateritic soil used was obtained from an existing borrow pit at Lagelu, Igbo-Elerin, Ibadan, Oyo State, Nigeria (latitude $7^{\circ} 25^{\prime} \mathrm{N}$ and longitude $5^{\circ} 38^{\prime}$ E) at a depth of $\sim 1.5 \mathrm{~m}$. The sample was collected using the disturbed sampling approach (Agbede and Manasseh, 2008). The geotechnical properties of the soil as determined in this study for the purpose of its classification are presented in Table 4 . Testing was carried out at the Soil Laboratory of the Civil Engineering Department of the University of Ibadan in accordance with the BS 1377 (BSI, 1990).

\subsubsection{Water}

Based on the recommendations of BS 3148 (BSI, 1980) publicly supplied and untreated water with a chemical composition acceptable for drinking, as well as water from natural sources subjected to adequate physical treatment (e.g. filtration), is suitable for making concrete. In this study, the water 
Table 3. Chemical composition of lime

$\begin{array}{lc}\text { Compounds } & \text { \% (by weight) } \\ \text { Calcium oxide }(\mathrm{CaO}) & 62 \cdot 00 \\ \text { Silicon dioxide }\left(\mathrm{SiO}_{2}\right) & 22 \cdot 70 \\ \text { Aluminium oxide }\left(\mathrm{Al}_{2} \mathrm{O}_{3}\right) & 6 \cdot 84 \\ \text { Iron oxide }\left(\mathrm{Fe}_{2} \mathrm{O}_{3}\right) & 5 \cdot 22 \\ \text { Sulfur trioxide }\left(\mathrm{SO}_{3}\right) & 1.00 \\ \text { Magnesium oxide }(\mathrm{MgO}) & 1 \cdot 00 \\ \text { Manganese oxide }(\mathrm{MnO}) & 0.02 \\ \text { Potassium oxide }\left(\mathrm{K}_{2} \mathrm{O}\right) & 0.49 \\ \text { Titanium dioxide }\left(\mathrm{TiO}_{2}\right) & 0.14 \\ \text { Sodium oxide }\left(\mathrm{Na}_{2} \mathrm{O}\right) & 0.08 \\ \text { Loss of ignition } & 10.20\end{array}$

Table 4. Geotechnical properties of the soil

\begin{tabular}{lc|} 
Property & Value \\
\hline Natural moisture content: \% & $14 \cdot 27$ \\
Gravel: \% & $7 \cdot 08$ \\
Sand: \% & $65 \cdot 18$ \\
Clay: \% & $27 \cdot 20$ \\
Coefficient of curvature & $1 \cdot 2$ \\
Coefficient of uniformity & $6 \cdot 7$ \\
USCS classification & $\mathrm{SP}$ \\
Liquid limit & 48 \\
Plastic limit & $36 \cdot 33$ \\
Plastic index & $11 \cdot 67$ \\
Specific gravity & $2 \cdot 63$ \\
Conditioned sample & Air-dried \\
Colour & Reddish brown
\end{tabular}

used for the mixing the constituent materials of the concretes produced was filtered rain water obtained from the Soil Laboratory of the Civil Engineering Department of the University of Ibadan. Filtration was carried out to remove any suspended matter and to ensure conformity with BS 3148 (BSI, 1980) requirements.

\subsection{Mixture proportioning and moulding of bricks and blocks}

The laterite soil sample was stabilised with $0-10 \%$ cement or lime. Cement proportions of $0,2,4,6,8$ and $10 \%$ were measured by weight of laterite for the laterite-cement mixtures. Lime proportions of $0,2,4,6,8$ and $10 \%$ were also measured by weight of laterite for the laterite-lime mixtures. Block specimens of size $225 \mathrm{~mm} \times 100 \mathrm{~mm} \times 100 \mathrm{~mm}$ and brick specimens of size $200 \mathrm{~mm} \times 100 \mathrm{~mm} \times 100 \mathrm{~mm}$ (BS 1377 (BSI, 1990)) were moulded from the stabilised lateritic soil samples. A total of 12 blocks were moulded with two blocks for each percentage of stabilising material (cement). In the same manner and under the same conditions, bricks were also produced and cured for $28 \mathrm{~d}$. To ensure an even distribution of blows in the mould, an $\sim 100 \mathrm{~mm}$ square sheet

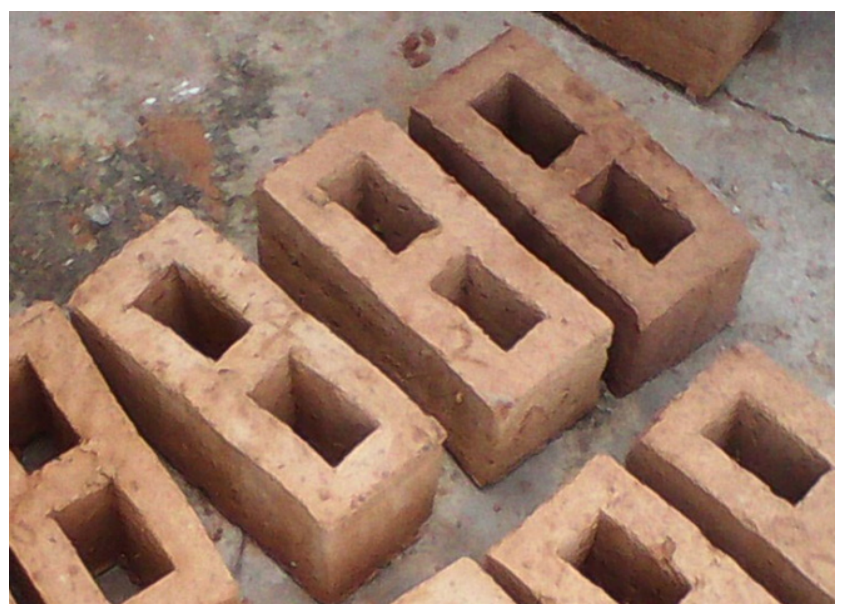

Figure 1. Freshly moulded blocks

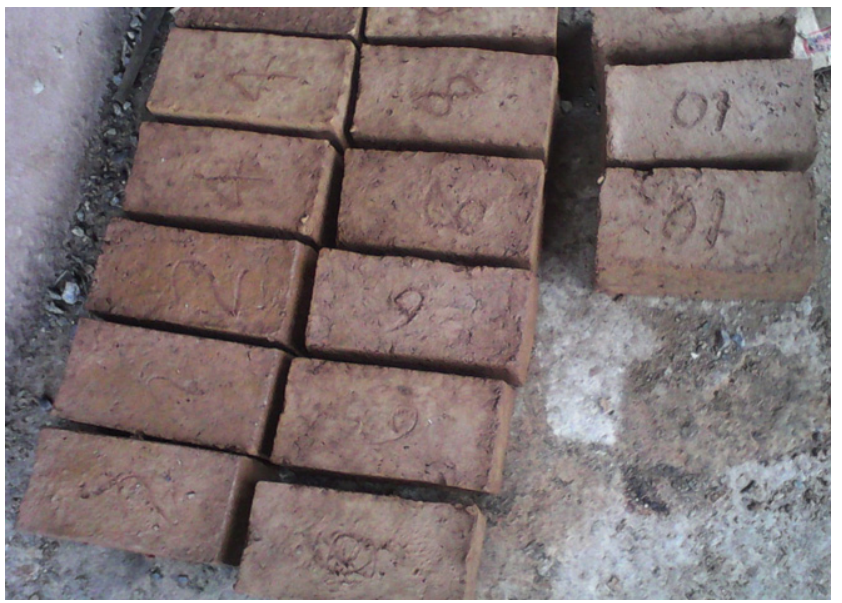

Figure 2. Freshly moulded bricks

of $12.5 \mathrm{~mm}$ thick plywood was placed on the mixture in the mould and compaction was done in accordance with BS 1377 (BSI, 1990). The freshly moulded blocks (Figure 1) and bricks (Figure 2) were carefully extruded in good shape on a clean, hard and flat surface. All the moulded cement/limestabilised laterite bricks and blocks were left to cure in the open air under normal temperature for $28 \mathrm{~d}$. Water was sprayed on the blocks/bricks once in the morning and once in the evening for the $28 \mathrm{~d}$ curing period (Okeke and Ekere, 2012).

\subsection{Water absorption test}

The principle of water absorption testing is to immerse a face of a masonry unit in water for a particular period and determine the increase in mass. The bricks were immersed in $5 \mathrm{~mm}$ depth of water for $10 \mathrm{~min}$. The gross area of the test face and the 
Table 5. Physical characteristics of lime- and cement-stabilised laterite blocks and bricks

\begin{tabular}{llll} 
& & Characteristics \\
\cline { 2 - 4 } & Colour change & Crack pattern \\
\hline Cement-stabilised block & Reddish brown to whitish brown at $4 \mathrm{~d}$ curing age & Tiny cracks observed & Rapid hydration at $1 \mathrm{~d}$ curing age \\
Lime-stabilised block & Reddish brown to light brown after $10 \mathrm{~d}$ of curing & No cracks & Slow hydration after $7 \mathrm{~d}$ curing \\
Unstabilised block & Reddish brown to deep brown & No visible cracks & Slow hydration \\
Cement-stabilised brick & Reddish brown to whitish brown at $4 \mathrm{~d}$ curing observed & Rapid hydration at $1 \mathrm{~d}$ curing \\
Lime-stabilised brick & Reddish brown to light brown after $10 \mathrm{~d}$ of curing & No visible cracks & Slow hydration at 7 d curing \\
Unstabilised brick & Reddish brown to deep brown & No visible cracks & Very slow hydration
\end{tabular}

increase in brick weight were measured. The initial rate of absorption was calculated as the ratio of increase in mass and gross area in $10 \mathrm{~min}$. The water absorption is the ratio of increase in mass and dry mass expressed as a percentage (Malisa et al., 2014).

\subsection{Compressive strength test}

Compressive strength is the capacity of a material or structure to withstand loads tending to reduce size. It is a key value in the design of structures and is often measured using a universal compressive strength testing machine. The compressive strengths of the stabilised laterite blocks and bricks were determined in accordance with the procedure for pre-cast concrete blocks. Two samples each of the stabilised laterite bricks were crushed in a compression testing machine with metal plates placed above and below the brick. Load was then placed axially and uniformly until failure occurred. The maximum failure load on the brick was measured. This load divided by the cross-sectional area of the brick gave the compressive strength of the brick. The compressive strength tests of the specimens were carried out in accordance with BS 3921:1985 (BSI, 1985) and BS 1881-115 (BSI, 1986).

\section{Results and discussion}

\subsection{Physical properties of bricks and blocks}

The physical changes observed after casting the bricks and blocks are presented in Table 5. The colour of the cementstabilised samples changes from reddish brown to whitish brown at $4 \mathrm{~d}$ curing age and the lime-stabilised samples changed from a reddish brown colour to a light brown colour after $10 \mathrm{~d}$ of curing. The colour of the unstabilised samples only changed from reddish brown to deep brown over the entire duration of curing. The phenomenon of colour change is common in materials made from stabilised lateritic soil; a similar observation was reported by Awoyera and Akinwumi (2014). In soil science, the colour of the surface of a soil depends on its mineralogical composition, surface morphology and moisture level (Bedidi et al., 1992). Thus, the change in colouration of the samples at different curing ages may be attributed to various factors, including the rate of hydration in the blocks/bricks (which technically

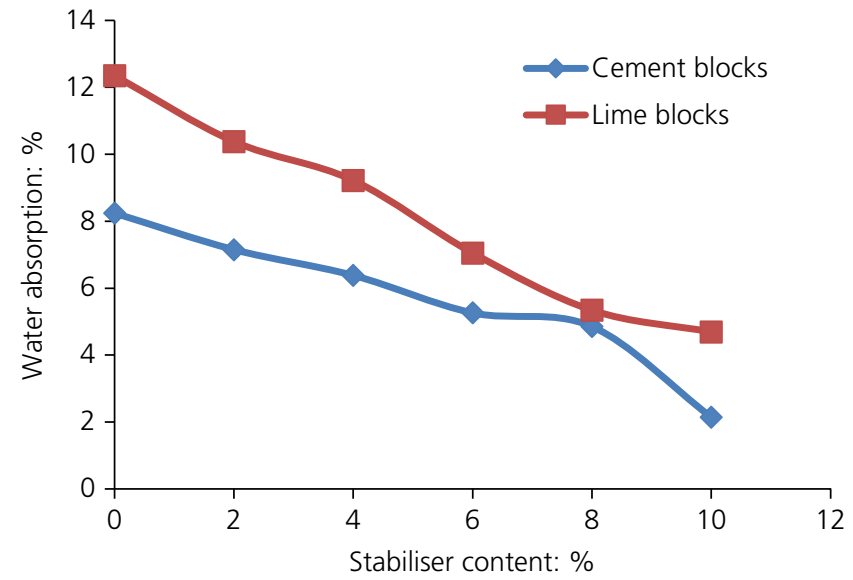

Figure 3. Water absorption characteristics of cement- and lime-stabilised lateritic blocks

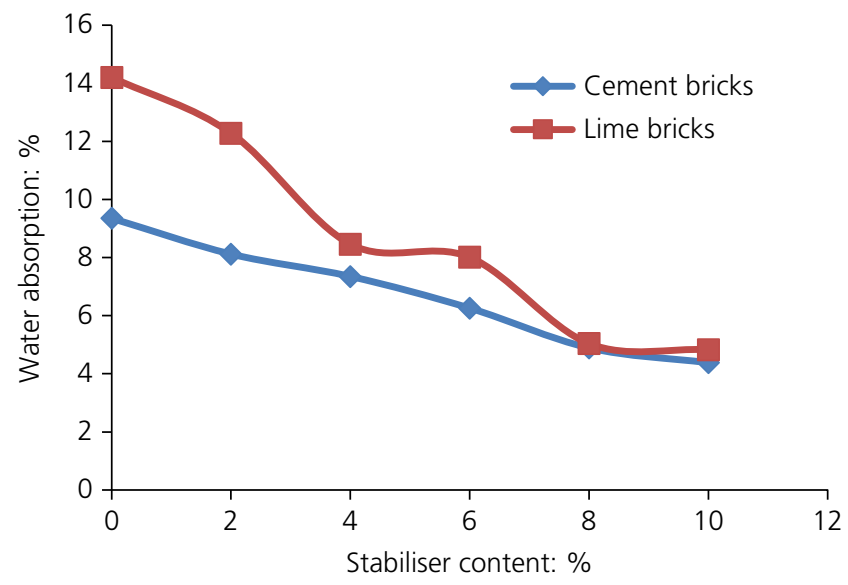

Figure 4. Water absorption characteristics of cement- and lime-stabilised lateritic bricks

controls the moisture level) and the chemical reactions between oxides present in the soil and the stabilising agents applied. The rate of hydration tended to increase as the amount of cement 
Table 6. Compressive strengths of $0-10 \%$ cement- and lime-stabilised blocks

\begin{tabular}{|c|c|c|c|c|c|c|c|c|}
\hline \multirow[b]{3}{*}{ Stabiliser content: \% } & \multicolumn{8}{|c|}{ Compressive strength: $\mathrm{N} / \mathrm{mm}^{2}$} \\
\hline & \multicolumn{4}{|c|}{ Cement } & \multicolumn{4}{|c|}{ Lime } \\
\hline & $7 d$ & $14 \mathrm{~d}$ & $21 d$ & $28 d$ & $7 d$ & $14 \mathrm{~d}$ & $21 d$ & $28 d$ \\
\hline 0 & 0.85 & 1.46 & $1 \cdot 58$ & 1.64 & 0.85 & 1.46 & 1.58 & 1.64 \\
\hline 2 & 0.94 & $1 \cdot 52$ & 1.65 & 1.82 & 0.90 & 1.47 & 1.61 & $1 \cdot 70$ \\
\hline 4 & 0.99 & 1.68 & 1.80 & 1.95 & 0.94 & $1 \cdot 52$ & 1.63 & 1.73 \\
\hline 6 & $1 \cdot 10$ & 1.73 & 1.85 & $2 \cdot 28$ & 0.98 & $1 \cdot 58$ & 1.67 & $1 \cdot 85$ \\
\hline 8 & 1.14 & 1.82 & 1.92 & $2 \cdot 35$ & 1.09 & 1.63 & $1 \cdot 70$ & 1.88 \\
\hline 10 & $1 \cdot 18$ & 1.88 & 2.05 & $2 \cdot 42$ & $1 \cdot 12$ & 1.65 & $1 \cdot 74$ & 1.97 \\
\hline
\end{tabular}

present in the samples increased. The cement reaction with moisture gives rise to hydration (Awoyera and Akinwumi, 2014). The colour change was less noticeable in the lime-stabilised bricks and blocks, and this could be attributed to the slower hydration process of the lime mixtures. This could be a result of the content of lime, which might have affected the samples' reaction with moisture. The tiny cracks observed in the cementstabilised bricks and blocks could be a result of the rapid hydration that occurred between 1 and $7 \mathrm{~d}$; this stabilised after $7 \mathrm{~d}$ and cracking did not continue.

\subsection{Water absorption characteristics of cement- and lime-stabilised lateritic blocks and bricks}

The water absorption characteristics of the blocks and bricks at $28 \mathrm{~d}$ are presented in Figures 3 and 4. The plots show that the percentage water absorption for both blocks and bricks decreased with increasing percentage of stabiliser (i.e. cement or lime). At $28 \mathrm{~d}$ curing age, the laterite-lime bricks and blocks absorbed more water as compared with the lateritecement bricks and blocks. The water absorption was only considered at $28 \mathrm{~d}$ due to the low rate of early strength development experienced at a lower curing age, which may be due to weather conditions at the time of experiment. This suggests that the lime-stabilised blocks were more permeable than the cementstabilised blocks for the same percentage of stabilisation. This was also the case for the bricks. Both the stabilised blocks and bricks satisfied the maximum water absorption of $12 \%$ as recommended by NIS 87-2 (SON, 2004) (Oshodi, 2004; Raheem et al., 2010). This is in contrast to the unstabilised blocks and bricks, which showed a water absorption slightly higher than $12 \%$.

\subsection{Compressive strength characteristics of cement- and lime-stabilised blocks and bricks}

\subsubsection{Cement- and lime-stabilised lateritic blocks}

The compressive strengths of the cement- and lime-stabilised lateritic blocks are presented in Table 6 and Figure 5. The compressive strength increased with increasing percentages of cement or lime for all the curing ages.

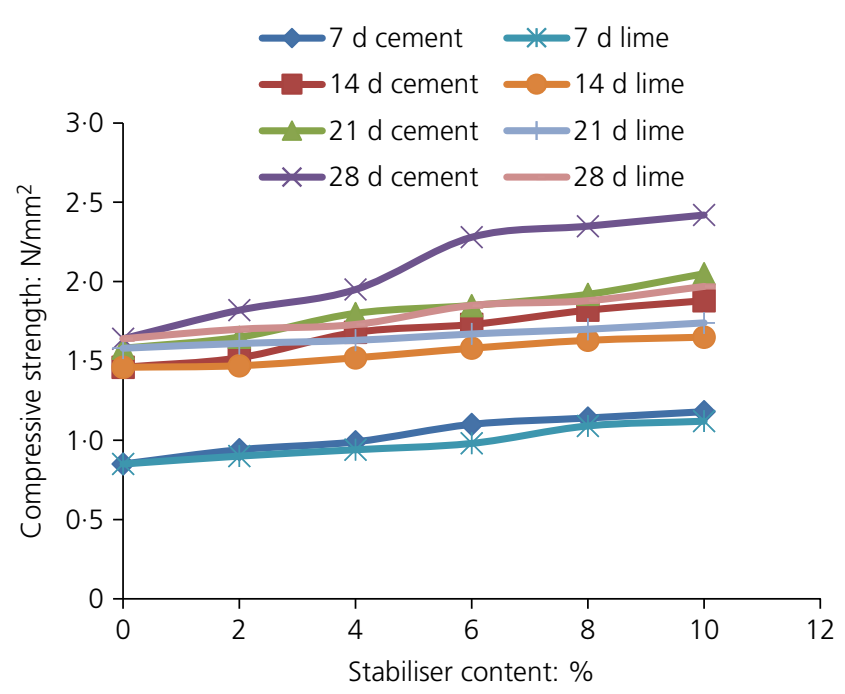

Figure 5. Compressive strengths of $0-10 \%$ cement- and lime-stabilised blocks

The maximum compressive strengths of $1 \cdot 18,1.88,2.05$ and $2.42 \mathrm{~N} / \mathrm{mm}^{2}$ were obtained at 7, 14, 21 and $28 \mathrm{~d}$, respectively, for block specimens stabilised with a $10 \%$ cement content. These values fall below the standard compressive strength specified by BS 6073 (BSI, 1981) and NIS 87 (SON, 2000) for load-bearing blocks.

For the lime-stabilised blocks, maximum compressive strengths of $1.12,1.65,1.74$ and $1.97 \mathrm{~N} / \mathrm{mm}^{2}$ were obtained at $7,14,21$ and $28 \mathrm{~d}$, respectively, for specimens stabilised with $10 \%$ lime content. Again, these values are below the standard compressive strength for load-bearing blocks specified by BS 6073 (BSI, 1981) and NIS 87 (SON, 2000).

BS 6073 (BSI, 1981) recommends $2 \cdot 8 \mathrm{~N} / \mathrm{mm}^{2}$ and NIS 87 (SON, 2000) specifies a minimum compressive strength of $2.5 \mathrm{~N} / \mathrm{mm}^{2}$ for individual load-bearing blocks and an average compressive strength of $3.45 \mathrm{~N} / \mathrm{mm}^{2}$. However, at 21 and $28 \mathrm{~d}$ curing ages, 
Table 7. Compressive strengths of $0-10 \%$ cement- and lime-stabilised bricks

\begin{tabular}{|c|c|c|c|c|c|c|c|c|}
\hline \multirow[b]{3}{*}{ Stabiliser content: \% } & \multicolumn{8}{|c|}{ Compressive strength: $\mathrm{N} / \mathrm{mm}^{2}$} \\
\hline & \multicolumn{4}{|c|}{ Cement } & \multicolumn{4}{|c|}{ Lime } \\
\hline & $7 d$ & $14 d$ & $21 d$ & $28 d$ & $7 d$ & $14 d$ & $21 d$ & $28 \mathrm{~d}$ \\
\hline 0 & 1.03 & 1.52 & $1 \cdot 62$ & 1.81 & 1.00 & 1.53 & 1.62 & 1.80 \\
\hline 2 & $1 \cdot 12$ & 1.60 & 1.77 & 1.98 & 1.06 & 1.58 & 1.66 & 1.84 \\
\hline 4 & $1 \cdot 15$ & $1 \cdot 74$ & 1.96 & 2.03 & $1 \cdot 11$ & 1.62 & $1 \cdot 80$ & 1.91 \\
\hline 6 & $1 \cdot 24$ & 1.87 & 2.04 & $2 \cdot 37$ & $1 \cdot 13$ & 1.74 & $1 \cdot 87$ & 1.95 \\
\hline 8 & $1 \cdot 32$ & 1.92 & $2 \cdot 11$ & 2.46 & $1 \cdot 15$ & 1.80 & 1.92 & $2 \cdot 16$ \\
\hline 10 & $1 \cdot 50$ & $2 \cdot 33$ & $2 \cdot 26$ & $2 \cdot 64$ & 1.62 & 1.84 & $2 \cdot 01$ & $2 \cdot 36$ \\
\hline
\end{tabular}

the cement-stabilised blocks satisfied the $2 \cdot 0 \mathrm{~N} / \mathrm{mm}^{2}$ recommended by the Nigerian Building and Road Research Institute (NBRRI, 2006). Also, at 14, 21 and $28 \mathrm{~d}$, both the cement- and lime-stabilised blocks satisfied the $1.6 \mathrm{~N} / \mathrm{mm}^{2}$ recommended by the National Building Code (NBC, 2006) for minimum $7 \mathrm{~d}$ dry compressive strength for $5 \%$ cement-stabilised blocks.

The results also show that the cement-stabilised blocks attained a higher strength than the lime-stabilised blocks at the same percentage stabilisation and curing age. This might be a result of the high rate of hydration reaction between cement and water, which probably influenced the faster hardening of the cementstabilised blocks (NIS 87 (SON, 2000)). The inconsistent strength increment might be a result of discrepancies in the applied compacting force during manual moulding.

In masonry technology, the quality of masonry blocks is usually affected by the quality of the constituent materials and the mix ratio (Baiden and Tuuli, 2004). The conventional masonry blocks to which British Standards apply are customarily made from normal coarse natural sand or crushed stone dust (devoid of deleterious matter and clay soil) mixed with cement in specified proportions (usually 1:6 cement:sand (Baiden and Tuuli, 2004; BSI, 1975), indicating $14 \%$ cement content) or $1: 4 \cdot 5$ cement:sand for hollow units with a web thickness not less or equal to $25 \mathrm{~mm}$ (Baiden and Tuuli, 2004; BSI, 1975), indicating $18 \%$ cement content). Thus, the lower compressive strength displayed by the stabilised block samples compared with the requirement of British Standards may be attributed to a number of factors, including the lateritic soil utilised as aggregate, the cement content (maximum of 10\% compared with the $14 \%$ and/or 18\% recommended by BS 2028 (BSI, 1975) for nominal masonry block mix ratio) and the type of binder utilised.

\subsubsection{Cement- and lime-stabilised lateritic bricks}

As shown in Table 7 and Figure 6, the maximum compressive strengths of the cement-stabilised bricks at $10 \%$ stabilisation were $1 \cdot 50,2 \cdot 26,2.33$ and $2 \cdot 64 \mathrm{~N} / \mathrm{mm}^{2}$ at $7,14,21$ and $28 \mathrm{~d}$ curing ages, respectively. The lime-stabilised bricks at $10 \%$

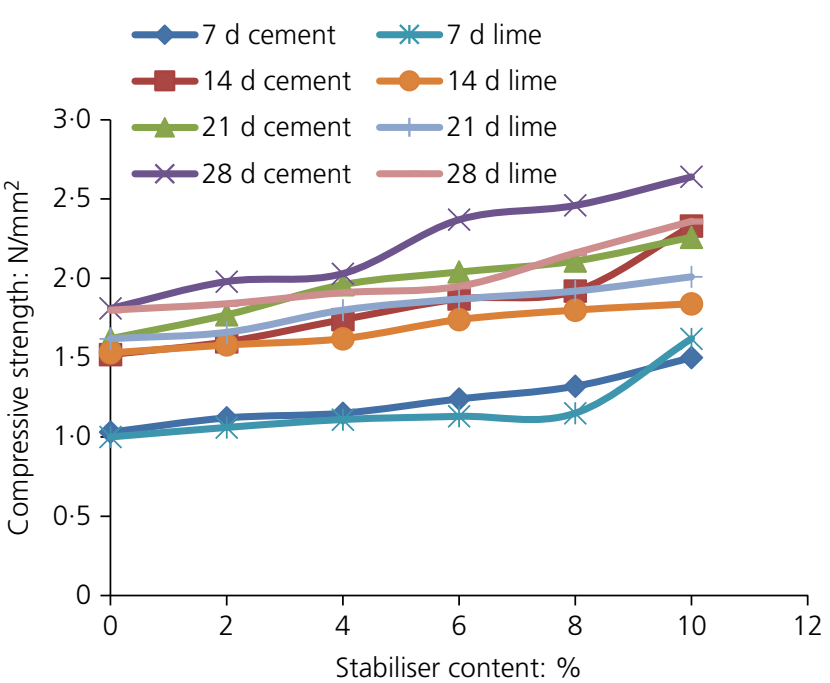

Figure 6. Compressive strengths of $0-10 \%$ cement- and lime-stabilised bricks

stabilisation exhibited compressive strengths of $1 \cdot 50,1 \cdot 84$, $2 \cdot 01$ and $2 \cdot 36 \mathrm{~N} / \mathrm{mm}^{2}$ at $7,14,21$ and $28 \mathrm{~d}$, respectively. The results thus indicate that the bricks gained strength with increased stabiliser content and also with curing age. Laterite bricks according to the Nigerian Building and Road Research Institute (NBRRI, 2006) should have a compressive strength of $1.65 \mathrm{~N} / \mathrm{mm}^{2}$ and a durability of $6.9 \%$ with a maximum cement content fixed at $5 \%$. The test samples complied with this condition, starting from $14 \mathrm{~d} 4 \%$ stabilisation to $28 \mathrm{~d} 10 \%$ stabilisation for cement, and from $14 \mathrm{~d} 6 \%$ stabilisation to $28 \mathrm{~d} 10 \%$ stabilisation for lime.

It was also noticed, as noted in the moulding process, that the bricks made with cement gained strength faster than those with lime stabiliser. This could be attributed to the slower rate of hydration in the lime-stabilised bricks (Raheem et al., 2010). It was therefore deduced that cement stabilisation would be preferable where early strength is targeted in the field. 
The bricks had higher compressive strengths than the blocks. This is basically due to the hollowness of the blocks, which results in a reduction in the area resisting the compressive load applied. In addition, in masonry technology, the compressive strengths of elements made from similar constituent materials are usually affected by the confinement effect (Barbosa and Hanai, 2009), which means that bricks and blocks made from similar constituents tend to display different compressive strengths due to differences in geometries/external dimensions. In most cases, brick units usually displays higher strength due to their compact size (Hendry, 1998). The higher strength displayed by the bricks compared with the block samples may also thus be attributed to the small size of the bricks compared with the blocks.

\section{Conclusions}

This study has revealed the effects of cement and lime stabilisation of lateritic blocks and bricks. The water absorption pattern in the stabilised blocks and bricks was regular; it decreased with an increase in the percentage of stabiliser added. Compressive strength tests revealed that cement-stabilised blocks and bricks had higher compressive strengths than those stabilised with lime. The stabilised blocks and bricks experienced an increase in strength with curing age and percentage stabilisation.

The increase in compressive strength with an increase in percentage of stabiliser could be due to increased bonding within the aggregates of the lateritic soil. Metcalfe (1977) noted that, in general, strength increase is in direct proportion to cement content, but at different rates for different soils. However, a higher cement content may result in a prohibitive cost, which places laterite-cement blocks/bricks at a disadvantage.

Traditionally, lateritic soils, which are reddish brown in colour, have been used in blocks for buildings without any cement content. Recently, modern builders have started introducing some percentage of cement into laterite for moulding stronger blocks, due to the high cost of sandcrete blocks. A major advantage of using laterite instead of sand in moulding building blocks is low cost, due to the small quantity of cement required to produce blocks with adequate compressive strengths as well as low cost of obtaining laterite. Aguwa (2009) reported that small amounts of cement inhibit the weakening effect of water and increase the strength. The results of the current study showed that the compressive strength of lateritecement blocks and bricks increased steadily with increases in the percentage of cement content.

Therefore, considering the findings of this study and the availability of laterite soil deposits (especially in Nigeria), the use of laterite can be well harnessed for the production of low-cost laterite-cement and laterite-lime blocks and bricks. It is thus suggested that lateritic blocks stabilised with cement could be used as alternatives to sandcrete blocks in the construction of non-high-rise buildings. Lime-stabilised laterite blocks and bricks are also recommended for use in non-load-bearing/ non-structural partition walls in building structures.

\section{REFERENCES}

Adam EA and Agib ARA (2001) Compressed Stabilized Earth Block Manufactured in Sudan. Unesco, Paris, France.

Agbede IO and Manasseh J (2008) Use of cement-sand admixture in laterite bricks production for low cost housing. Leonardo Electronic Journal of Practices and Technologies 7(12): 163-174.

Aguwa JI (2009) Study of compressive strengths of laterite-cement mixes as a building material. AU Journal of Technology 13(2): $114-120$.

Amu OO, Bamisaye OF and Komolafe IA (2011) The suitability and lime stabilization requirement of some lateritic soil samples as pavement. International Journal of Pure and Applied Sciences and Technology 2(1): 29-46.

Awoyera PO and Akinwumi II (2014) Compressive strength development for cement, lime and termite-hill stabilised lateritic bricks. International Journal of Engineering and Science 3(2): 37-43.

Baiden BK and Tuuli MM (2004) Impact of quality control practices in sandcrete blocks production. Journal of Architectural Engineering 10(2): 53-60.

Barbosa CS and Hanai JB (2009) Strength and deformability of hollow masonry blocks: correlation of block and cylindrical sample test results. IBRACON Structures and Materials Journal 2(1): 85-99.

Bedidi A, Cervelle B, Madeira J and Pouget M (1992) Moisture effects on visible spectral characteristics of lateritic soils. Soil Science 153(2): 129-141.

BSI (1975) BS 2028: Precast concrete blocks. BSI, London, UK.

BSI (1980) BS 3148: Tests for water for making concrete. BSI, London, UK.

BSI (1981) BS 6073-1: Precast concrete masonry units, specification for precast concrete masonry units. BSI, London, UK.

BSI (1985) BS 3921: Specification for clay bricks. BSI, London, UK.

BSI (1986) BS 1881-115: Specification for compression testing machines for concrete. BSI, London, UK.

BSI (1990) BS 1377: Methods of testing for soils for civil engineering purposes. BSI, London, UK.

BSI (2000) BS EN 197-1: Cement - part 1: composition, specification and conformity criteria for common cements. BSI, London, UK.

Encyclopaedia Britannica (2016) http://www.britannica.com/science/ laterite (accessed 26/03/2016).

Garber NJ and Hoel LA (2000) Traffic and Highway Engineering, 2nd edn. Brooks/Cole, Pacific Grove, CA, USA.

Hendry AW (1998) Structural Masonry, 2nd edn. Macmillan Press Ltd, London, UK.

Malisa AS, Park E and Lee J (2014) Effect of lime on physical properties of natural pozzolana from Same, Tanzania. International Journal of Engineering Research and Technology 3(11): 1357-1361.

McNally GH (1998) Soil and Rock Construction Materials. Routledge, London, UK

Metcalfe JB (1977) A Laboratory Investigation of Strength/Age Relations of Five Soils Stabilized with White Hydrated Lime and Ordinary Portland Cement, RN/3435/JBM. DSIR, RRI, Washington, DC, USA.

Nagaraj HB, Sravan MV, Arun TG and Jagadish KS (2014) Role of lime with cement in long term strength of compressed stabilized earth blocks. International Journal of Sustainable Built Environment 3(1): 54-61. 
NBC (National Building Code) (2006) Strength requirement for sandcrete block. Nigerian Building Code section: 10.3.14.4. Lexus and Nexis, Nigeria.

NBRRI (Nigerian Building and Road Research Institute) (2006) NBRRI interlocking block making machine. NBRRI Newsletter 1(1): $15-17$.

Ogunbiyi MA, Akinola SR, Oginni FA and Akerele E (2014) Comparative study of cement stabilized clay brick and sandcrete block as a building component. International Journal of Applied Science and Technology 4(6): 56-61.

Okeke OC and Ekere JT (2012) Effects of variation of sand and laterite mixtures on the compressive strength of bricks. Journal of Applied Science and the Environment 3(1): 49-53.
Oshodi OR (2004) Techniques of Producing and Dry Stacking Interlocking Blocks. Nigerian Building and Road Research Institute Workshop on Local Building Materials, Ota, Nigeria.

Raheem AA, Bello OA and Makinde OA (2010) A comparative study of cement and lime stabilized lateritic interlocking blocks. Pacific Journal of Science and Technology 11(2): 27-34.

SON (Standard Organisation of Nigeria) (2000) NIS 87: Standard for sandcrete blocks. SON, Abuja, Nigeria.

SON (2003) NIS 444-1: Cement - part 1: composition, specification and conformity criteria for common cements. SON, Abuja, Nigeria.

SON (2004) NIS 87-2: Standards for sandcrete blocks. SON, Abuja, Nigeria.

\section{How can you contribute?}

To discuss this paper, please email up to 500 words to the editor at journals@ice.org.uk. Your contribution will be forwarded to the author(s) for a reply and, if considered appropriate by the editorial board, it will be published as discussion in a future issue of the journal.

Proceedings journals rely entirely on contributions from the civil engineering profession (and allied disciplines). Information about how to submit your paper online is available at www.icevirtuallibrary.com/page/authors, where you will also find detailed author guidelines. 